\title{
Retinoblastoma Clinical Regional Lymph Nodes TNM Finding v8
}

National Cancer Institute

\section{Source}

National Cancer Institute. Retinoblastoma Clinical Regional Lymph Nodes TNM Finding v8. NCI Thesaurus. Code C140700.

A clinical finding about one or more characteristics of retinoblastoma, following the rules of the TNM AJCC v8 classification system as they pertain to staging of regional lymph nodes. 